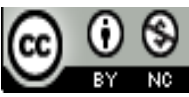 \\ JurnalTerapanManajemendan Bisnis is licensed under \\ A Creative Commons Attribution-NonCommercial 4.0 International License.
}

\title{
RAK ACCESSORIES FUNNY
}

\section{Wahyuni Oktavia(1), Zulfahita ${ }^{2)}$,Siwi Sukmawati D. N3), Syahwan'), Yuniati Yuyun ${ }^{5)}$}

1) Universitas Negeri Sebelas Maret Surakarta, Solo, Indonesia

E-mail: oktaviawahyuni9@gmail.com

2) STKIP Singkawang, Singkawang, Indonesia

E-mail: zulfahita@yahoo.co.id

3) STKIP Singkawang, Singkawang, Indonesia

E-mail: siwisukmawati7@gmail.com

4) STKIP Singkawang, Singkawang, Indonesia

E-mail: syahwansyahkete@gmail.com

5) STKIP Singkawang, Singkawang, Indonesia

E-mail: yuniatiyuyun253@gmail.com

\begin{abstract}
Student creativity program in this entrepreneurship class, we run a business program of making cute accessory shelves from used cardboard. This used cardboard is very easy to get at the nearest shops or buy and sell used goods and the price is also quite affordable. Besides being easy to get, used cardboard is also easy to make several forms of crafts, one of which is a shelf. The shelf that we are going to make is a small shelf model where this shelf is made in various shapes, which will make many people like these models. Here what we need in addition to tools and materials is that we need skills and strong creative power. So that the shelves that we will create can attract consumers to buy. In the community, there are many unique shelves that make consumers want to buy them, but the price is a little less affordable for consumers' wallets. Therefore we take advantage of this situation to make cute accessory racks in order to help consumers more comfortable arranging their accessories or makeup with hemp by using this cute accessory rack that we made. The form of our business is that it is still in an individual stage and indeed this business is still new and is still trying to enter the business world. But we already have our own business brand, namely "RASEL" which means Cute Accessories Rack. In the future, if this business can get extraordinary profits and have enough customers, then we will increase this business to be even bigger.
\end{abstract}

Keywords: accessories rack, cardboard, creativity

\section{Introduction}

Did you know, used cardboard that is rarely used by people can actually channel good ideas into our heads. Even in creative hands, used cardboard can be transformed into unique and of course useful handicraft items.

"Craft is something that is valued as alternative creativity, an item produced through hand skills" (Raharjo, 2011: 15). 
Making used cardboard crafts, it is not as complicated as we imagine, it is quite a bit of our accuracy and creativity. Used cardboard is also very easy to find in stores or buying and selling used goods. At first glance, this used cardboard is cardboard that is of no use, but actually this used cardboard can be used as a useful product. This used cardboard can be used as a craft item such as a unique and cute accessory rack.

\section{Literature Review}

\section{A. Product Uniqueness}

Used cardboard that is made into a shelf, of course, has a lot of benefits, as for the advantages of our products are:

a. Cheap and affordable prices

b. Has a variety of unique shapes

c. Providing benefits for consumers to arrange accessories so that they look tidier and more organized.

"A product is something that can be offered to the market to be noticed, used, owned, or consumed so that it can satisfy wants or needs" (Firmansyah, 2019:2).

\section{B. Market Share}

Our target market is teenagers and housewives. We determine our marketing location later through social media and our closest friends because it is more effective. We will market our products on our social accounts. And we will offer it to friends around our environment.

\section{Business Location}

The location of the business is very important and very supportive for the development or failure of a business in the future. In determining the location of our business, we choose the available social media as well as in our residential area.

\section{Research Methods}

\section{A. Environmental Observations}

Conduct environmental observations of the environment around us. The goal is to observe the surrounding environment to find business opportunities that can develop well in the future.

\section{B. Marketing Strategy}

We will do a marketing strategy to start our business success by using used cardboard to become shelves then selling them and offering our products to various other consumers and not forgetting to promote our products on our social media.

"Marketing is a process of a person or organization to influence other people or other organizations so that those who want and need a product or service can be fulfilled and those who have the product or service benefit" (Darmanto and Sri Wardaya, 2016: 5).

\section{Tools and Materials}

Table 1. Material

\begin{tabular}{lll}
\hline No & \multicolumn{1}{c}{ Tool } & \multicolumn{1}{c}{ Materials } \\
\hline 1. & Pencil & Used cardboard \\
2. & Ruler & Fox glue \\
3. & Kater & Jombo Size Wrapping Paper \\
4. & Scissors & Wool yarn \\
5. & Glue Shoot Tool & Glue Shoot \\
6. & & Paper Solution \\
\hline
\end{tabular}




\section{Result and Discussion}

\section{A. Business Preparation}

The business preparation here is to prepare any equipment needed to start marketing our products.

"Business is someone's effort in managing products or goods sold, services sold for profit" (Sembiring, 2014: 3-4).

\section{B. Starting a Business}

The utilization of this used cardboard can be done with very thorough preparation. Cooperation in one group will facilitate and speed up an activity carried out. Here's how to make used cardboard into a cute accessory rack:

1. Prepare the used cardboard box that will be made for the accessory rack and cut it into pieces according to the size of the shelf to be made.

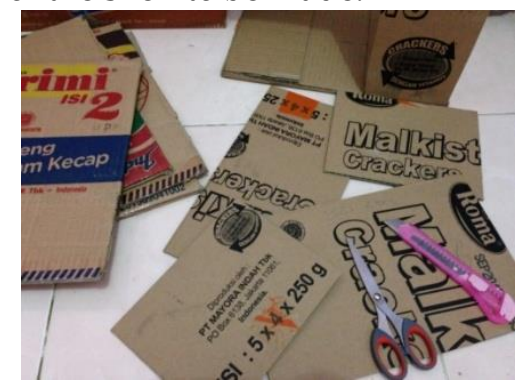

Picture 1. Prepare

2. If you have cut the cardboard according to the desired size, then stick the wrapping paper that has been measured according to the cardboard pieces that have been cut earlier.

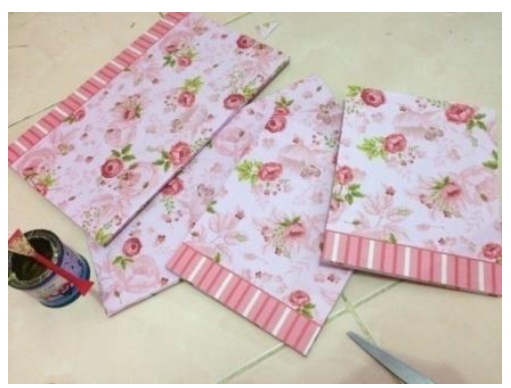

Picture 2. Process

3. After sticking the wrapping paper to the cardboard that has been cut earlier, then glue it using hot glue to make it stronger on the edges to make it into a shelf shape according to your wishes

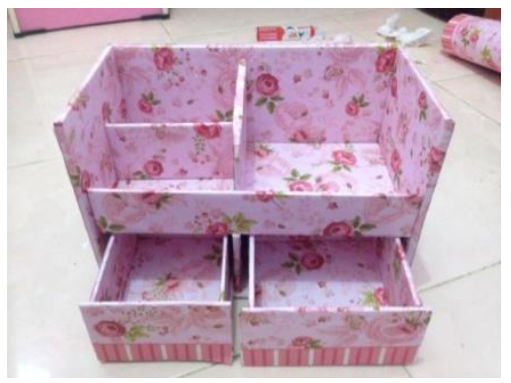

Picture 3. Process 
4. If you have attached all parts of the shelf, make the decorations as you wish and the cute accessory rack is ready to use

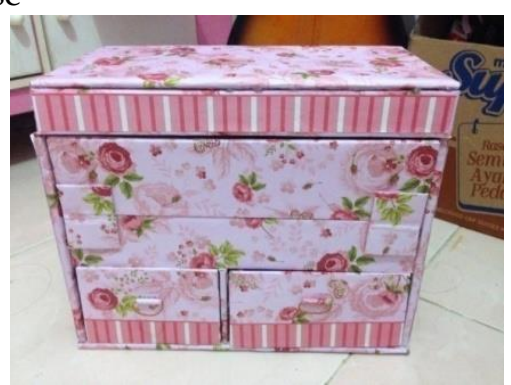

Picture 3. product results

\section{Place of Sale}

We will market the products that we have made to various consumers around the environment and we will sell them through social media.

\section{Research Implications}

As we know, used cardboard is easy to find in characters and selling used goods. We can use it or recycle the cardboard in one way, namely making the cardboard an accessory shelf. For people with this creativity, it will indirectly help consumers in fulfilling their personal needs in arranging accessories and makeup to make it look neat without having to rely on goods from outside the region. Make it easy for people to get unique items. The benefit of this used cardboard shelf is that it makes the arrangement of accessories or makeup tidier and the shelves look more unique.

The creation of an independent business that can contribute to the surrounding community. Products that are produced from used cardboard into accessories shelves are very diverse and of course very useful for arranging your accessories or makeup.

"Implications are everything that has been produced by the policy formulation process. In other words, implications are the consequences and consequences caused by the implementation of certain policies or activities" (Islamy, 2003: 114-115).

\section{Conclusion}

This accessory rack is a handicraft made from unused cardboard. We have to look for used cardboard that is rather strong so that when cutting the shelves it looks straighter and stronger.

\section{References}

Raharjo, Timbul (Ed.). 2011. Seni Kriya \& Kerajinan. Yogyakarta: Program Pascasarjana.

Darmanto, Sri Wardaya. 2016. Manajemen Pemasaran Untuk Mahasiswa, Usaha Micro, Kecil dan Menengah. Yogyakarta: Deepublish.

Sembiring, Rasmulia (Ed.). 2014. Pengantar Bisnis. Bandung: La Goods Publishing.

Firmansyah, M. Anang. 2019. Pemasaran Produk dan Merek. Jakarta: Penerbit Qiara Media. Islamy, Irfan. 2003. Prinsip-Prinsip Perumusan Kebijaksanaan Negara. Jakarta: Bina Aksara. 